\title{
Phospholipid synthesis in the preimplantation mouse embryo
}

\author{
Hester P. M. Pratt
}

Department of Anatomy, University of Cambridge, Downing Street, Cambridge CB2 3DY, U.K.

\begin{abstract}
Summary. Synthesis of phospholipid during cleavage, compaction and blastocyst formation of the preimplantation mouse embryo was investigated using [methyl- ${ }^{3} \mathrm{H}$ ]choline as a specific precursor. The only choline-containing lipids found to incorporate label were phosphatidylcholine and lysolecithin. [Methyl- ${ }^{3} \mathrm{H}$ ]choline incorporation into lipid was detectable at the 2-cell stage and increased 9-13-fold (on a per embryo basis) during the 8-cell stage and subsequent compaction of the morula. Incorporation of choline was also elevated in the blastocyst but could not be compared accurately with the rates observed in earlier embryos due to uncertainty about the size of the endogenous choline pool at this stage. Choline kinase (assayed in vitro) was detectable at every stage, its activity increased during development and paralleled (qualitatively) the extent of phosphocholine formation in intact embryos. Phospholipid turnover and choline base exchange did not contribute significantly to [methyl ${ }^{3} \mathrm{H}$ ]choline incorporation into lipid, which is hence judged to represent denovo synthesis of phospholipid via the Kennedy pathway.

Mouse embryo lipids exhibit several features which may be characteristic of immature cells and which could influence the properties of their membranes. These include the absence of detectable sphingomyelin synthesis and the presence of demonstrable deacylation and turnover of phosphatidylcholine.
\end{abstract}

\section{Introduction}

The proliferation and integrity of cellular membranes is likely to be an important controlling factor in the differentiation of the preimplantation mouse embryo. Not only do the cellular changes associated with cleavage and the subsequent growth of the embryo require the assembly of new intracellular and plasma membranes (Calarco \& Brown, 1969) but striking qualitative changes in the properties of embryonic membranes also occur during crucial transitions in early development. For example, compaction of the morula leads to polarization of cells (Ducibella, Albertini, Anderson \& Biggers, 1975; Ducibella, Ukena, Karnovsky \& Anderson, 1977), generating zonular tight junctions around the periphery of the embryo and establishing intercellular contact between internal cells, an arrangement which may be very important for the subsequent differentiation of the embryo (discussed by Johnson, Handyside \& Braude, 1977; Johnson, 1979). Modulations in the organization of intracellular and plasma membranes can also be inferred from variations in surface antigen expression (Edidin, 1976), changes in mitochondrial morphology and membrane-bound enzyme activity (Biggers \& Borland, 1976) as well as the transition from $\mathrm{Na}^{+}$-dependent to $\mathrm{Na}^{+}$-independent amino acid transport (Borland \& Tasca, 1974) and localized activity of $\mathrm{Na}^{+}-\mathrm{K}^{+}$ATPase during accumulation of blastocoelic fluid (Biggers, Borland \& Powers, 1977).

Despite this evidence that membrane organization can reflect and may influence the progress of embryonic differentiation, there has been no systematic attempt to investigate the capacity of the preimplantation mammalian embryo to synthesize and assemble new intracellular and 
plasma membranes. In addition, very little attention has been devoted to the structural lipids of mammalian embryo membranes despite the fact that lipids comprise approximately half the membrane (Rothman \& Lenard, 1977), are known to influence the fluid and enzymic properties of membranes (Lee, 1975; Kimelberg, 1977), and can determine the growth and differentiation potential of experimentally or pathologically modified cells (Horwitz, Hatten \& Burger, 1974; Cooper, 1977; Pratt, 1978). Since phospholipids are major structural components of all membranes (Rothman \& Lenard, 1977) and there is a negligible pool of free phospholipid in the cell (Kuff, Hymer, Shelton \& Roberts, 1966) these lipids are useful indicator molecules for both intracellular and plasma membranes (Pasternak \& Bergeron, 1970).

The present study of phospholipid synthesis in the preimplantation mouse embryo used [methyl- ${ }^{3} \mathrm{H}$ ]choline as a specific precursor for choline-containing phospholipids, one of the major classes of phospholipids (Bergeron, Warmsley \& Pasternak, 1970; Rothman \& Lenard, 1977).

\section{Materials and Methods}

\section{Embryo culture}

Outbred female mice of the CFLP strain (Anglia Laboratories, U.K.) were induced to superovulate with an intraperitoneal injection of 5 i.u. PMSG (Folligon: Intervet, U.K.) followed 44$48 \mathrm{~h}$ later by 5 i.u. hCG (Chorulon: Intervet, U.K.) and mated with CFLP males. Mating was confirmed by the presence of a vaginal plug the following morning. Cleavage-stage embryos were obtained by flushing the oviducts, and blastocysts by flushing uteri, with PB 1 medium containing $10 \%$ fetal calf serum (FCS) (Whittingham \& Wales, 1969). Embryos were staged by taking the time of hCG injection as $0 \mathrm{~h}$. Two-cell embryos were obtained at $38-48 \mathrm{~h}, 8$-cell precompaction embryos at 60-62 h, post-compaction morulae (approx. 12 cells) at 74-76 h and early expanding blastocysts (approx. 60 cells) at 88-90 h, after hCG.

The labelling medium consisted of embryo culture medium $+4 \mathrm{mg}$ bovine serum albumin (BSA)/ml (Biggers, Whitten \& Whittingham, 1971) and the specified concentration of [methyl${ }^{3} \mathrm{H}$ ]choline chloride (sp. act. $10 \mathrm{Ci} / \mathrm{mmol}$ : Radiochemical Centre, Amersham, U.K.). The media were made up by drying down a small volume $(10-50 \mu \mathrm{l})$ of the stock ethanolic solution of [methyl ${ }^{3} \mathrm{H}$ ]choline chloride under vacuum, and dissolving it in 10-50 $\mu$ l of the medium to make the required concentration of choline. For choline concentrations above $1.0 \mathrm{~mm}$ the isotope was diluted with a stock solution of non-radioactive choline $(1 \mathrm{M})$. Embryos were washed in culture medium + BSA and placed in small drops of the radioactive medium, pre-equilibrated with $95 \%$ air $+5 \% \mathrm{CO}_{2}$ at $37^{\circ} \mathrm{C}$ for $30 \mathrm{~min}$, within $2 \mathrm{~h}$ of removal from the genital tract. The drops of medium were covered with paraffin oil and cultured in an atmosphere of $95 \%$ air $+5 \% \mathrm{CO}_{2}$ at $37^{\circ} \mathrm{C}$ for various lengths of time. Duplicate groups of 5-10 embryos per group were then washed rapidly 8-10 times in non-radioactive medium containing $1 \mathrm{~mm}$-choline. If the radioactivity in the final wash fluid exceeded $5 \%$ of the radioactivity remaining associated with the embryos, then the embryos were discarded. Removal of the zona pellucida did not affect uptake or incorporation of choline and embryos were therefore incubated with their zonae intact.

\section{Lipid extraction}

Trichloroacetic acid (TCA) precipitation. In preliminary experiments to saturate the endogenous choline pools of embryos, [methyl- $\left.{ }^{3} \mathrm{H}\right]$ choline incorporation into TCA-insoluble material was used to measure choline incorporation into lipid (as described by Pasternak, 1973). About $95-99 \%$ of this acid-insoluble material was solublized with chloroform: methanol $(2 / 1 \mathrm{v} / \mathrm{v})$ and TCA-precipitated phosphatidylcholine was as stable as chloroform : methanol-extracted lipid if stored at $-10^{\circ} \mathrm{C}$ and analysed within $24 \mathrm{~h}$.

All extraction procedures were carried out using $1.0 \mathrm{ml}$ conical Pyrex tubes (Dupont, U.K.) 
and a $50 \mu \mathrm{l}$ Hamilton syringe for washing extracts and recovering supernatants. Labelled embryos were lysed in $20 \mu \mathrm{H}_{2} \mathrm{O}$ containing $100 \mu \mathrm{g}$ BSA and disrupted by 2 cycles of freezethawing and vortexing. Then $100 \mu \mathrm{g}$ egg-yolk phosphatidylcholine were added and labelled lipids were extracted by adding an equal volume of $20 \% \mathrm{TCA}$, leaving the samples at $-10^{\circ} \mathrm{C}$ overnight and recovering the precipitates by centrifugation (Pasternak, 1973). [Methyl- ${ }^{3} \mathrm{H}$ ]phosphatidylcholine, [methyl- ${ }^{3} \mathrm{H}$ ]lysolecithin and [methyl- ${ }^{14} \mathrm{C}$ ]sphingomyelin (Radiochemical Centre, Amersham, U.K.) were used to ascertain that the combination of BSA and phosphatidylcholine as co-precipitants was sufficient to provide quantitative recovery of these phospholipids. Three washes with $10 \mu \mathrm{l} 5 \%$ TCA were sufficient to remove all acid-soluble radioactivity from the precipitate, and these washes were combined with the initial supernatant and counted in Tritontoluene scintillation fluid with an efficiency of $15-20 \%$.

Acid-insoluble radioactivity was determined by depositing the material on GF/C filters, washing and drying the filters in the conventional manner (Pasternak, 1973; Pratt, 1977), and counting them in Triton-toluene scintillation fluid at $15-20 \%$ efficiency. [Methyl- ${ }^{3} \mathrm{H}$ ]choline incorporation into acid-insoluble material was equated with incorporation into lipid by several criteria: (1) $95-99 \%$ of acid-insoluble material was solubilized by chloroform : methanol $(2: 1$ $\mathrm{v} / \mathrm{v}$ ) (Pasternak, 1973); (2) the radioactivity was resistant to proteolytic digestion by pronase; and (3) $100 \%$ of the [methyl $-{ }^{3} \mathrm{H}$ ]choline-labelled material could be recovered from the thin-layer plates as phospholipids. Individual phospholipids were identifiable by their susceptibility to alkaline hydrolysis (Dawson, 1960) and treatment with phospholipase C (Simpson \& Hauser, 1966). Total uptake of $\left[\right.$ methyl- $\left.{ }^{3} \mathrm{H}\right]$ choline is expressed per 10 embryos as the sum of acidinsoluble and acid-soluble radioactivity.

Chloroform:methanol extraction. For qualitative analysis of labelled lipid, embryos were lysed in $20 \mu \mathrm{H} \mathrm{H}_{2} \mathrm{O}$, dissolved immediately in $0.2 \mathrm{ml}$ chloroform : methanol $(2: 1 \mathrm{v} / \mathrm{v})$ and then washed twice by the method of Folch, Lees \& Sloane-Stanley (1957) as modified by Pasternak (1973) before being stored at $-70^{\circ} \mathrm{C}$. When extracted and stored under these conditions the chromatographic profile of the lipids remained unchanged for more than $48 \mathrm{~h}$, and $95 \%$ of the material was TCA-precipitable.

\section{Chromatographic techniques}

After centrifugation of the TCA extract the acid-soluble supernatant was removed from the precipitate, stored at $-10^{\circ} \mathrm{C}$ and analysed within $48 \mathrm{~h}$. The analysis was conducted on thin-layer plates of cellulose with reference to known standards using two different solvent systems (Textfig. 1) to confirm the identity of labelled components: (1) n-butanol : ethanol : acetic acid : $\mathrm{H}_{2} \mathrm{O}$ $\left(8: 2: 1: 3\right.$ by vol) (Plagemann, 1968); (2) chloroform :methanol: $\mathrm{NH}_{4} \mathrm{OH}(65: 45: 8$ by vol) (Yorio \& Bentley, 1976). Reference standards consisting of choline, phosphocholine, glycerophosphocholine and cytidine diphosphocholine (CDP-choline) were identified by exposure to iodine vapour or elution and spectrophotometric assay (Plagemann, 1968). This procedure confirmed quantitative recovery of all species. Radioactive samples were analysed by cutting the plastic-coated cellulose plate into strips and allowing the material to elute into $1.0 \mathrm{ml} \mathrm{H}_{2} \mathrm{O}$ for 24 $\mathrm{h}$ at room temperature. The eluate was then counted in $10 \mathrm{ml}$ Triton-toluene scintillation fluid. The recovery of applied counts was $55-60 \%$ under these conditions but could be increased to $70-80 \%$ with no change in the relative proportions of the components if a second identical elution was performed. Counts (or pmol radioactive choline) incorporated into acid-soluble components are expressed per 10 embryos and corrected for incomplete recovery.

Thin-layer chromatographic analyses of $\left[\right.$ methyl- $\left.{ }^{3} \mathrm{H}\right]$ choline-labelled lipid was carried out (immediately if possible or within $48 \mathrm{~h}$ of extraction) on thin-layer (t.l.c.) plates of silica gel $\mathrm{G}$ with reference to known standards using the solvent chloroform : methanol: $\mathrm{NH}_{4} \mathrm{OH}(65: 25: 5$ by vol.) as described by Pratt, Fitzgerald \& Saxon (1977) (Text-fig. 1). Recovery of radioactivity from the plates was $95-98 \%$. Labelled lipids were identified (1) by their $R_{\mathrm{F}}$ values (Text- 
fig. 1) and (2) by their susceptibility to alkaline hydrolysis (Dawson, 1960). Counts (or pmol of radioactive choline) incorporated into lipid are expressed per 10 embyros.

\section{Choline kinase assay}

Choline kinase was assayed as described by Schneider (1969). Embryos (in groups of 10) were lysed in $10 \mu \mathrm{H}_{2} \mathrm{O}$ and disrupted by freeze-thawing and vortexing twice. An equal volume of the reaction mixture, consisting of $40 \mathrm{mM}$-Tris succinate, $\mathrm{pH} 7.5,6 \mathrm{mM}-\mathrm{MgCl}_{2}, 4.8 \mathrm{mM}-\mathrm{ATP}$, pH 7.0, $32 \mathrm{~mm}$ 3-phosphoglyceric acid, pH 7.0, $84 \mathrm{~mm}-\mathrm{NaCl}$, and $0.016 \mathrm{~mm}-\left[\mathrm{methyl}-{ }^{3} \mathrm{H}\right]-$ choline, was then added and the tubes were vortexed and incubated at $37^{\circ} \mathrm{C}$ for $1 \mathrm{~h}$. Enzyme activity was proportional to substrate concentration for all embryonic stages over the range 0.005-0.02 mM-choline under these conditions. The extent of conversion of [methyl- $\left.{ }^{3} \mathrm{H}\right]$ choline into phosphocholine was determined by chromatography on cellulose thin-layer plates as described above. Samples containing culture medium alone did not convert any [methyl- $\left.{ }^{3} \mathrm{H}\right]-$ choline into phosphocholine.

\section{Results}

\section{Uptake and incorporation of $\left[\right.$ methyl $\left.{ }^{3} H\right]$ choline}

Preliminary experiments demonstrated that uptake of [methyl- $\left.{ }^{3} \mathrm{H}\right]$ choline by 2 -cell embryos, morulae and blastocysts was linear with time for periods up to $6 \mathrm{~h}$ and was proportional to the number of embryos assayed. The labelled choline was considered to be transported into the
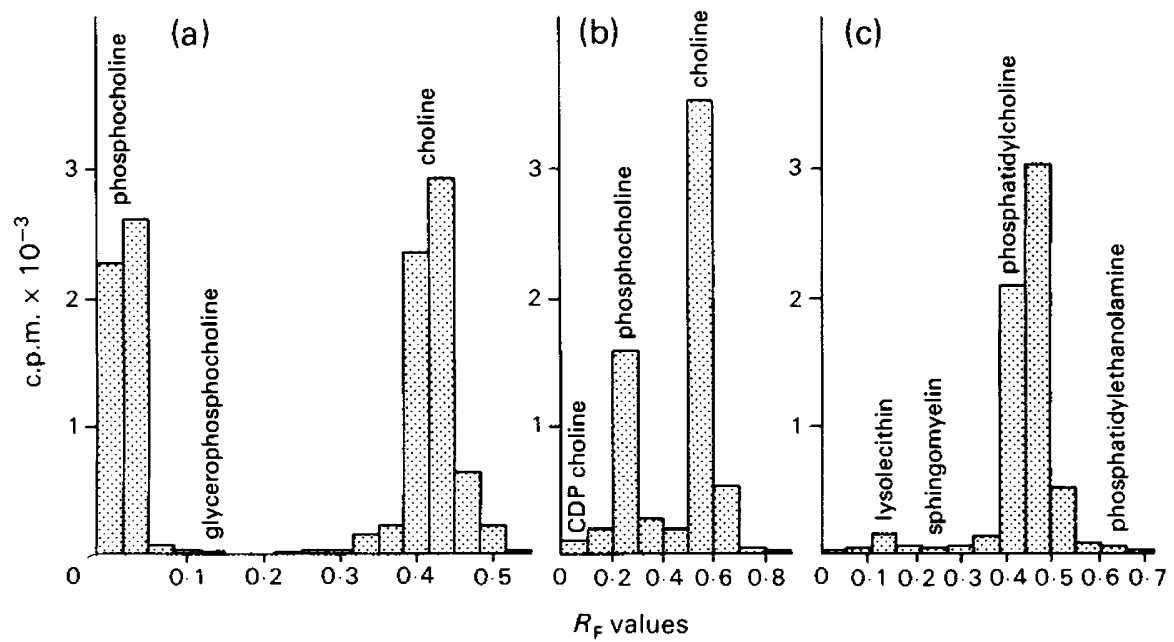

Text-fig. 1: a and b: Representative chromatographic profiles of [methyl ${ }^{3} \mathrm{H}$ ]choline-labelled acid-soluble components in mouse embryos. Embryos were incubated in $0.25 \mathrm{~mm}$-[methyl- ${ }^{3} \mathrm{H}$ ]choline for $4 \mathrm{~h}$, washed and the acid-soluble material extracted and analysed (see 'Materials and Methods') on a cellulose thin-layer plate with reference to known standards using the solvents (a) chloroform : methanol: $\mathrm{NH}_{4} \mathrm{OH}\left(65: 45: 8\right.$ by vol.) and (b) $n$-butanol : ethanol : acetic acid : $\mathrm{H}_{2} \mathrm{O}$ ( $8: 2: 1: 3$ by vol.). (c) Representative chromatographic profile of [methyl- ${ }^{3} \mathrm{H}$ ]choline-labelled lipid. Embryos were incubated in $0.25 \mathrm{~mm}-\left[\right.$ methyl- $\left.{ }^{3} \mathrm{H}\right]$ choline for $4 \mathrm{~h}$, washed, lysed and extracted with chloroform : methanol $(2: 1 \mathrm{v} / \mathrm{v})$ and then analysed on silica gel thin-layer plates with reference to known standards using the solvent chloroform : methanol: $\mathrm{NH}_{4} \mathrm{OH}(65: 25: 5$ by vol.). $R_{\mathrm{F}}$ indicates the mobility of each component compared with the solvent front. 
embryos rather than adhering to their external surfaces since it was not displaced by a range of choline concentrations in the washing medium. In all subsequent experiments duplicate groups of 10 embryos were incubated in radioactive choline for $4 \mathrm{~h}$. Acid-insoluble material was analysed within $24 \mathrm{~h}$ of TCA precipitation and was shown to be $>90 \%$ lipid by its solubilization in the chloroform:methanol solvent, lack of susceptibility to proteolytic digestion, complete hydrolysis by alkaline ethanol or phospholipase C (see 'Materials and Methods'), and identity with standard phospholipids analysed on t.l.c. plates (Text-fig. 1).

When incorporation of [methyl- $\left.{ }^{3} \mathrm{H}\right]$ choline into acid-insoluble lipid was measured as a function of external choline (Text-fig. 2) it approached saturation in 2-cell embryos and morulae at a choline concentration of 0.5-1.0 mM. On the other hand, incorporation of choline into lipid of early expanding blastocysts could not be saturated under the same experimental conditions. When [methyl- ${ }^{3} \mathrm{H}$ ] choline-labelled blastocysts were incubated with Cytochalasin $\mathrm{B}(10 \mu \mathrm{g} / \mathrm{ml})$ to collapse the blastocoele (Granholm \& Brenner, 1976), a 40\% reduction in acid-soluble radioactivity was obtained, suggesting that approximately $60 \%$ of the acid-soluble pool is intracellular. Acid-insoluble radioactivity was unaffected and neither acid-soluble nor acid-insoluble components were saturated after Cytochalasin B treatment.

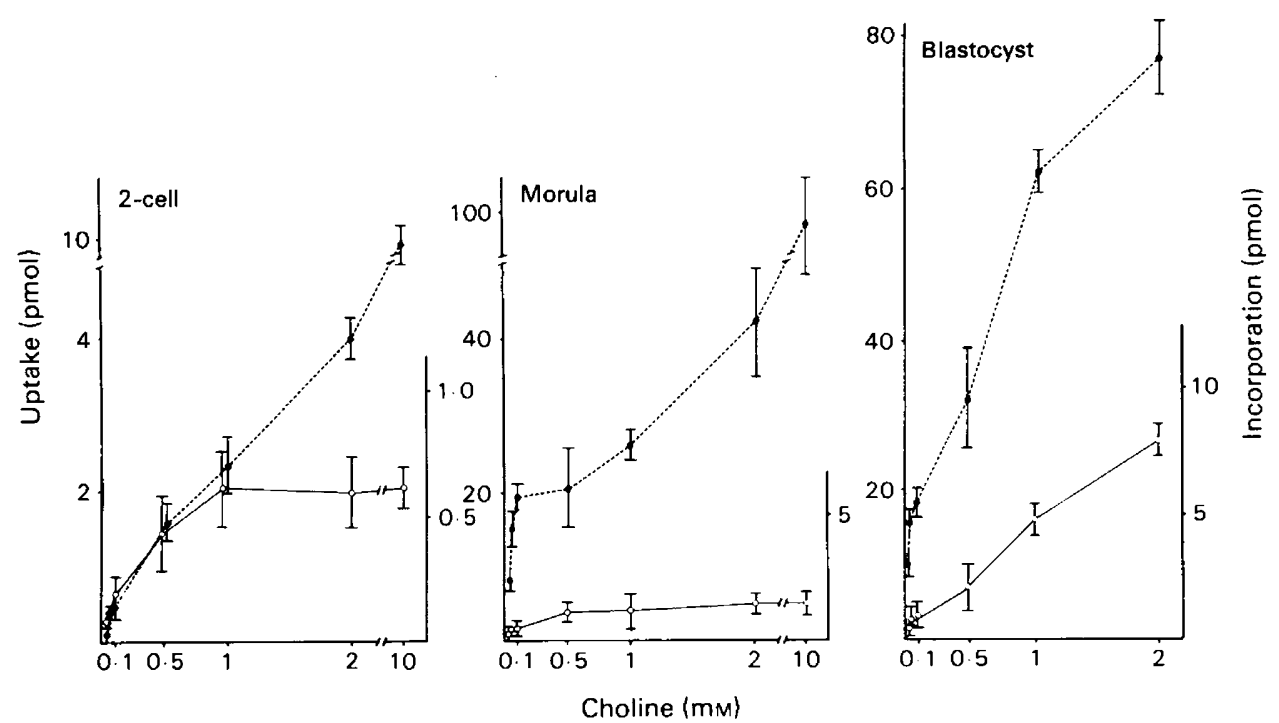

Text-fig. 2. Uptake

and incorporation (O

O) of $\left[\right.$ methyl- $\left.{ }^{3} \mathrm{H}\right]$ choline by mouse embryos at different developmental stages as a function of external choline concentration. Embryos at various stages (2-cell, 36-42 h after hCG; morula, 64-70 h after hCG; blastocysts, $88-94 \mathrm{~h}$ after hCG) were incubated in medium containing $0.0125 \mathrm{~mm}$ to $2.0 \mathrm{~mm}$ [methyl $\left.{ }^{3} \mathrm{H}\right]$ choline. Media containing up to $0.25 \mathrm{~mm}-\left[\right.$ methyl $\left.-{ }^{3} \mathrm{H}\right]$ choline were made up by varying the amount of isotope added, concentrations in excess of $0.25 \mathrm{~mm}$ being achieved by adding non-radioactive choline chloride. Embryos were incubated for $4 \mathrm{~h}$, washed, and the acid-soluble and acid-insoluble radioactivity determined as described in 'Materials and Methods'. Values given are expressed per 10 embryos and are the mean \pm s.d. of 4-6 determinations; 1 pmol is equivalent to $3 \times 10^{3} \mathrm{c}$.p.m. detected of [methyl- $\left.{ }^{3} \mathrm{H}\right]$ choline at $10 \mathrm{Ci} / \mathrm{mmol}$.

\section{Analysis of $\left[\right.$ methyl $\left.{ }^{3} \mathrm{H}\right]$ choline-labelled lipids and precursors}

Acid-soluble [methyl- ${ }^{3} \mathrm{H}$ ]choline-labelled lipid precursors from all embryonic stages were analysed by t.l.c. on plates of cellulose (for typical profiles, see Text-fig. 1). Choline and phosphocholine were the only labelled acid-soluble components to be detected; glycerophosphocholine and cytidine diphosphocholine were never observed (Text-fig. 1). The amount of $\left[{ }^{3} \mathrm{H}\right]$ - 
phosphocholine formed ranged from 15 to $45 \%$ of the labelled choline transported into the embryos, depending upon the developmental stage (Table 1).

Table 1. Incorporation of $\left[\right.$ methyl $\left.{ }^{3} \mathrm{H}\right]$ choline into phospholipids and phospholipid precursors by preimplantation mouse embryos

\begin{tabular}{|c|c|c|c|c|c|}
\hline Embryo stage & Uptake* & Phosphocholine* & Lysolecithin* & Phosphatidylcholine* & $\begin{array}{l}\text { Phospholipid } \\
\text { (pmol) }{ }^{\dagger}\end{array}$ \\
\hline 2-cellf & $3.9 \pm 1.4$ & $0.6 \pm 0.1$ & - & $0.49 \pm 0.12$ & 0.26 \\
\hline $\begin{array}{l}\text { Pre-compaction } \\
\text { morula }\end{array}$ & $121 \cdot 0 \pm 17 \cdot 0$ & $54 \cdot 8 \pm 2 \cdot 4$ & $0.06 \pm 0.01$ & $4.42 \pm 0.64$ & $2 \cdot 35$ \\
\hline $\begin{array}{l}\text { Post-compaction } \\
\text { morula }\end{array}$ & $218 \cdot 5 \pm 15 \cdot 0$ & $70 \cdot 6 \pm 4 \cdot 6$ & $0.19 \pm 0.02$ & $6.48 \pm 0.63$ & $3 \cdot 50$ \\
\hline Blastocyst & $188.5 \pm 4.4$ & $39 \cdot 3 \pm 1 \cdot 3$ & $0.06 \pm 0.01$ & $4.91 \pm 0.75$ & $2 \cdot 61$ \\
\hline
\end{tabular}

Embryos were cultured in groups of 10 embryos for $4 \mathrm{~h}$ in $1.0 \mathrm{~mm}$-[methyl- ${ }^{3} \mathrm{H}$ ]choline and the acid-soluble and chloroform:methanol-soluble material was analysed as described in 'Materials and Methods'.

* Expressed as c.p.m. $\times 10^{-3} / 10$ embryos, mean \pm s.d. for 3-4 determinations.

† Expressed as pmol [methyl- ${ }^{3} \mathrm{H}$ ]choline incorporated into phospholipid (i.e. phosphatidylcholine + lysolecithin); $1 \mathrm{pmol}$ [methyl- ${ }^{3} \mathrm{H}$ ] choline incorporated is equivalent to $1.9 \times 10^{3}$ c.p.m. detected.

$¥$ Analysed in groups of 30 embryos because of their low activity.

The [methyl- ${ }^{3} \mathrm{H}$ ]choline-labelled TCA-precipitated lipids were identified as phosphatidylcholine and lysolecithin by their $R_{\mathrm{F}}$ values (Text-fig. 1), susceptibility to alkaline ethanolic hydrolysis (Dawson, 1960) and digestion with phospholipase C (Simpson \& Hauser, 1966). Degradation of phosphatidylcholine to lysolecithin was extensive (15-45\%) if TCA-precipitated lipid was stored at temperatures above $-10^{\circ} \mathrm{C}$ for periods exceeding $24 \mathrm{~h}$. However, immediate extraction of embryonic lysates into chloroform:methanol $(2: 1 \mathrm{v} / \mathrm{v})$ and analysis within $48 \mathrm{~h}$ resulted in a more stable preparation with only $2-5 \%$ of labelled lipid appearing as lysolecithin (Table 1). The presence of phospholipase A-type activity in extracts of morulae and blastocysts was confirmed using phosphatidyl[methyl $\left.-{ }^{14} \mathrm{C}\right]$ choline. Phosphatidyl $\left[\right.$ methyl $\left.-{ }^{14} \mathrm{C}\right]$ choline remained stable when extracted and analysed under the conditions described above but was also deacylated to lysolecithin when incubated with lysates of unlabelled morulae or blastocysts before extraction (H. P. M. Pratt, unpublished observations).

Incorporation of [methyl- ${ }^{3} \mathrm{H}$ ]choline $(1.0 \mathrm{~mm})$ into phospholipid (Table 1) was detectable in 2-cell embryos and had increased 9-13-fold by the time compaction of the morula was complete. Blastocyst formation was not associated with any further increase in choline incorporation under these experimental conditions.

\section{Choline kinase activity}

The kinetics of appearance of $\left[{ }^{3} \mathrm{H}\right]$ phospholipid and $\left[{ }^{3} \mathrm{H}\right]$ phospholipid precursors were studied by continuous labelling of embryos with [methyl ${ }^{3} \mathrm{H}$ ]choline (Text-fig. 3 ). Choline uptake and incorporation into lipid were linear over a $5 \mathrm{~h}$ period in embryos of all stages. To assess whether the amount of phosphocholine formed in intact embryos was related to the activity of the choline phosphorylating enzyme, choline kinase, this enzyme was assayed in extracts of the different embryonic stages, as described by Schneider (1969) (see 'Material and Methods'). Choline kinase activity in embryo extracts increased from the 2-cell stage onwards, reaching a maximum in the post-compaction morula and then decreased in the blastocyst (Table 2). This pattern of enzyme activity was reflected qualitatively in the amount of phosphocholine formed by intact embryos during development (Table 2; Text-fig. 3). The increased choline kinase activity observed in the fully compacted morula (Table 2) was associated with enhanced 
[methyl- ${ }^{3} \mathrm{H}$ ]choline-labelling of phosphocholine and phospholipid (Text-fig. 3). At the blastocyst stage choline kinase activity and phosphocholine formation were reduced to levels similar to those of pre-compaction morulae (Table 2; Text-fig. 3) but without a concomitant reduction in accumulation of $\left[{ }^{3} \mathrm{H}\right]$ phospholipid.
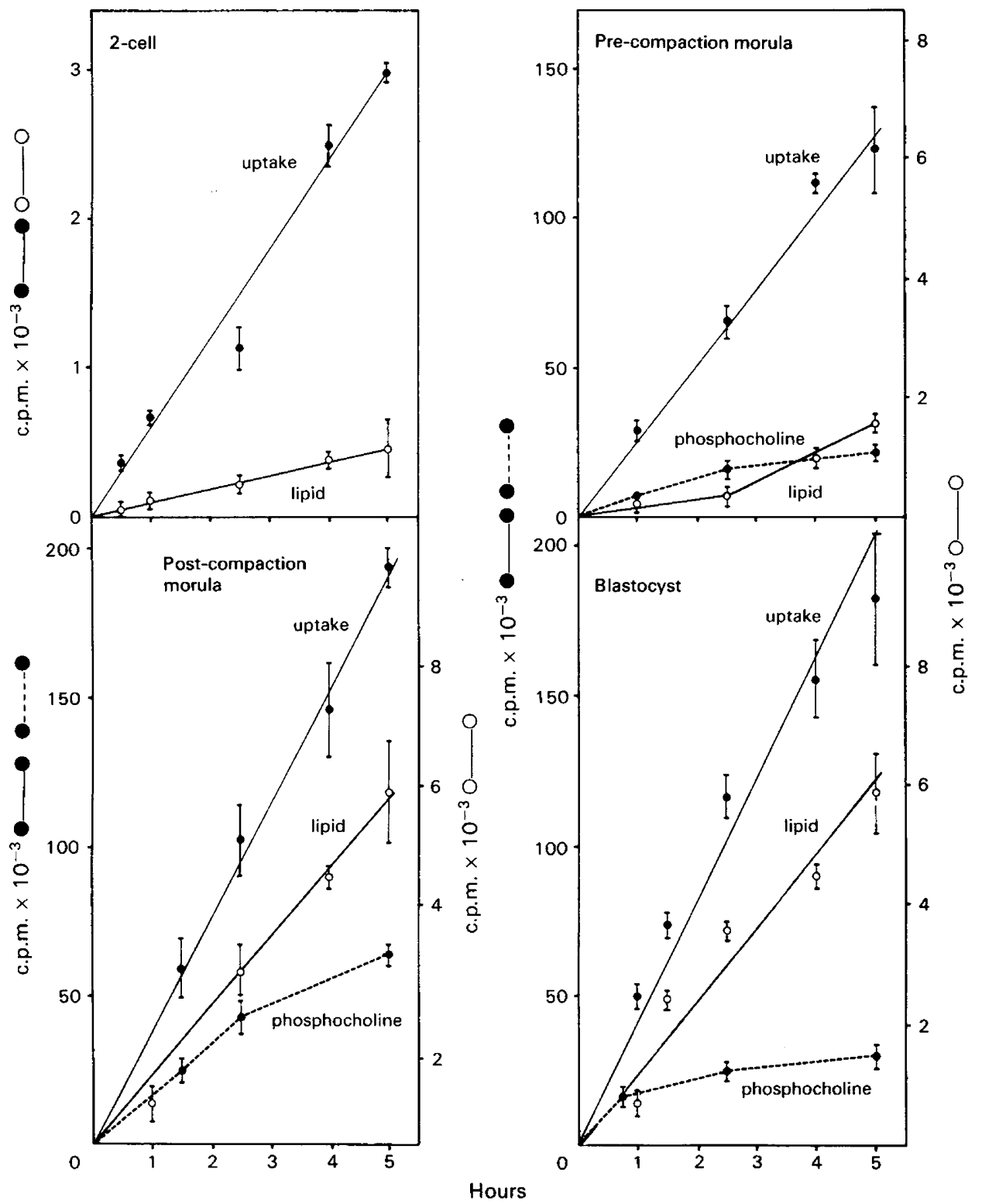

Text-fig. 3. Kinetics of uptake

) and incorporation of [methyl- $\left.{ }^{3} \mathrm{H}\right]$ choline into phospholipid (phosphatidylcholine + lysolecithin,

O) and its precursor, phosphocholine (- by mouse embryos. Embryos were incubated in $0.25 \mathrm{~mm}$-[methyl- $\left.{ }^{3} \mathrm{H}\right]$ choline and samples were removed at intervals for analysis of the labelled acid-soluble and chloroform:methanol-soluble components (for details see 'Materials and Methods'). Values are expressed per 10 embryos and given as the mean \pm s.d. of 3-4 determinations: $3 \times 10^{3}$ c.p.m. detected are equivalent to $1 \mathrm{pmol}\left[\right.$ methyl- $\left.{ }^{3} \mathrm{H}\right]$ choline. 
Table 2. Choline kinase activity (see 'Materials and Methods') in intact mouse embryos and embryo extracts

\begin{tabular}{lrrr}
\hline & \multicolumn{1}{c}{ In vitro } & \multicolumn{2}{c}{ In vivo } \\
\cline { 5 - 5 } \multicolumn{1}{c}{ Embryo stage } & Phosphocholine & Total uptake & Phosphocholine \\
\hline $\begin{array}{l}\text { 2-cell } \\
\begin{array}{l}\text { Pre-compaction } \\
\quad \text { morula }\end{array}\end{array}$ & $1.48 \pm 0.4$ & $0.59 \pm 0.1$ & $0.04 \pm 0.001$ \\
$\begin{array}{l}\text { Post-compaction } \\
\text { morula }\end{array}$ & $14.24 \pm 1.0$ & $119.1 \pm 13.0$ & $16.3 \pm 2.3$ \\
\begin{tabular}{l} 
Blastocyst \\
\hline
\end{tabular} & $9.28 \pm 1.3$ & $183.5 \pm 21.0$ & $22.0 \pm 3.2$ \\
\hline
\end{tabular}

Mean \pm s.d. values for 4-6 observations are expressed as c.p.m. $\times 10^{-3} / 10$ embryos.

\section{Stability of synthesized phospholipids}

Estimates of the stability of presynthesized phospholipid during embryonic development were made by labelling embryos with [methyl ${ }^{3} \mathrm{H}$ ] choline $12 \mathrm{~h}$ before they had reached the stage required, washing the embryos and replacing them in non-radioactive medium in the presence or absence of $1 \mathrm{~mm}$-choline. Groups of embryos and their culture media were assayed during the following $24 \mathrm{~h}$ (Table 3 ). Lipid-associated [methyl ${ }^{3} \mathrm{H}$ ]choline was lost progressively from every embryonic stage examined and was unaffected by the inclusion of $1 \mathrm{~mm}$-choline in the non-radioactive medium.

Table 3. Stability of phospholipid at different embryonic stages

\begin{tabular}{|c|c|c|c|c|c|}
\hline $\begin{array}{l}\text { Embryo stage } \\
\text { at start of } \\
\text { incubation }\end{array}$ & Choline & $\begin{array}{c}\text { Time in } \\
\text { non-radioactive } \\
\text { medium (h) }\end{array}$ & Total uptake* & {$\left[{ }^{3} \mathrm{H}\right]$ Phospholipid* } & $\begin{array}{l}\% \text { of initial } \\
\text { lipid remaining } \\
\text { after } 24 \mathrm{~h}\end{array}$ \\
\hline $\begin{array}{l}\text { Pre-compaction } \\
\text { morula }\end{array}$ & & 0 & $70 \cdot 5$ & $4 \cdot 1$ & 100 \\
\hline$(60 \mathrm{~h}$ after $\mathrm{hCG})$ & - & $\begin{array}{l}24 \\
24\end{array}$ & $\begin{array}{l}49 \cdot 2 \\
33.9\end{array}$ & $\begin{array}{l}2.4 \\
2.9\end{array}$ & $\begin{array}{l}59 \\
71\end{array}$ \\
\hline $\begin{array}{l}\text { Post-compaction } \\
\text { morula }\end{array}$ & & 0 & $114 \cdot 6$ & $9 \cdot 2$ & 100 \\
\hline (74 h after hCG) & $\overline{+}$ & $\begin{array}{l}24 \\
24\end{array}$ & $\begin{array}{r}104.8 \\
83.9\end{array}$ & $\begin{array}{l}8 \cdot 9 \\
8 \cdot 1\end{array}$ & $\begin{array}{l}96 \\
87\end{array}$ \\
\hline $\begin{array}{l}\text { Blastocyst } \\
\text { (84 h after hCG) }\end{array}$ & $\overline{+}$ & $\begin{array}{r}0 \\
24 \\
24\end{array}$ & $\begin{array}{r}183 \cdot 0 \\
103 \cdot 0 \\
83 \cdot 8\end{array}$ & $\begin{array}{l}5 \cdot 0 \\
3 \cdot 3 \\
4 \cdot 4\end{array}$ & $\begin{array}{r}100 \\
65 \\
88\end{array}$ \\
\hline
\end{tabular}

Embryos were recovered at 48,62 and $72 \mathrm{~h}$ after $\mathrm{hCG}$ and incubated for $12 \mathrm{~h}$ in $0.25 \mathrm{~mm}$ [methyl- ${ }^{3} \mathrm{H}$ ]choline until they had developed to pre-compaction morulae, post-compaction morulae and small blastocysts. Embryos were then washed in $1 \mathrm{~mm}$-choline and placed in $20 \mu \mathrm{l}$ non-radioactive medium $\pm 1 \mathrm{~mm}$ choline. Total uptake of [methyl $-{ }^{3} \mathrm{H}$ ]choline and its incorporation into chloroform:methanol-soluble phospholipid by embryos were analysed at the start of the incubation $(0 \mathrm{~h})$ and $24 \mathrm{~h}$ later. During this period the embryos developed to compacted morulae, small blastocysts and expanded blastocysts respectively. Total recovery of the initial radioactivity was $75-100 \%$.

* Expressed as c.p.m. $\times 10^{-3} / 10$ embryos.

\section{Discussion}

The aim of this study was to establish whether the preimplantation mouse embryo can synthesize a major group of phospholipids, and hence has the capacity to assemble membranes and regulate their lipid-mediated properties (Kimelberg, 1977). Methyl-labelled choline can be used as a specific precursor for studying the synthesis of choline-containing phospholipids and 
hence the assembly of new membranes (Nagley \& Hallinan, 1968; Bergeron et al., 1970), providing that precautions are taken to ensure that the radioactive methyl group is not being incorporated into serine, methionine or phosphatidylethanolamine. In this study, both acidinsoluble and chloroform : methanol-extracted lipid were resistant to proteolysis and the phosphatidylethanolamine fraction was unlabelled.

When measured as a function of external concentration, choline uptake by morulae and blastocysts, but not 2-cell embryos, occurs in a biphasic manner (Text-fig. 2) reminiscent of choline transport by hepatoma cells (Plagemann, 1971). Hepatoma cells accumulate choline by an active transport mechanism which is saturated at 10-20 $\mu \mathrm{M}$-choline; at higher concentrations choline enters the cell by simple diffusion. Using previous estimates of embryonic volume (Brinster, Wiebold \& Brunner, 1976) to calculate internal concentration of choline after incubating embryos for $4 \mathrm{~h}$ in $2 \mathrm{~mm}$-choline (Text-fig. 2) it appears that both morulae and blastocysts, but not 2-cell embryos, have the capacity to concentrate choline from the medium. Uptake of choline by 2 -cell embryos could therefore be entirely passive and similar to uridine and amino acid transport which both show altered kinetics between early cleavage and morula stages (Borland \& Tasca, 1974).

Choline was incorporated, almost exclusively, into phosphocholine, phosphatidylcholine and lysolecithin, which are all associated with the biosynthesis of choline-containing phospholipids via the Kennedy pathway (Kennedy, 1957). Intact embryos converted between 6 and $45 \%$ of transported choline into phosphocholine depending upon the developmental stage (Tables 1 and 2, Text-fig. 3). The extent of choline phosphorylation by intact embryos was paralleled qualitatively by the levels of choline kinase activity in lysates of embryos of equivalent developmental age (Table 2). Choline kinase activity (whether assayed in vivo or in vitro) was detectable at the 2-cell stage, increased during compaction and then decreased in the blastocyst. The incomplete phosphorylation of choline observed at every embryonic stage (Table 1, Text-fig. 3) has been found in other embryos (Pasternak, 1973) and is in contrast to the situation encountered with exponentially growing cells in which $100 \%$ of transported choline is phosphorylated (Plagemann, 1968, 1971). This could be due to a limitation of choline kinase in embryonic cells or the activity of an embryonic phosphatase acting on newly formed phosphocholine. The subsequent steps in the biosynthesis of phosphatidylcholine involve the formation of cytidine diphosphocholine (CDP-choline) from phosphocholine and cytidine triphosphate, and the reaction of CDP-choline with diacylglycerol to form phosphatidylcholine (Kennedy, 1957). Labelled CDP-choline was not detected in embryonic extracts (Fig. 1), a finding which is compatible with the very small pool size of this short-lived intermediate (Kennedy, 1957; Plagemann, 1968). Phosphocholine transferase was not measured directly in this study but its activity has previously been determined in the embryo, placenta and yolk sac of the 14-day rat embryo (Chepenik, Borst \& Waite, 1977).

Attempts to equilibrate the endogenous choline pool with external labelled choline and minimize any influence that limitations in choline transport, and hence intracellular specific activity, could have on choline incorporation into lipid were successful with the 2-cell embryo and morula. At an external choline concentration of $1.0 \mathrm{mM}$ the acid-insoluble lipid component saturated in the face of continuing choline uptake (Text-fig. 2). In the blastocyst, however, incorporation into lipid was not saturated over a similar concentration range. This could be due either to an inability to equilibrate the external medium with a large internal choline pool or due to a real failure to saturate synthetic mechanisms. Limitations in the numbers of embryos available have precluded any direct measurement of the choline content of mouse embryos; however, substantial (mM) endogenous choline pools have been found in unfertilized sea urchin eggs (Pasternak, 1973) and hepatoma cells (Plagemann, 1968).

Choline incorporation can only be used as an indication of phospholipid synthesis, and hence new membrane assembly (Bergeron et al., 1970; Pasternak, 1973), provided that the possibility of choline base exchange and extensive phospholipid turnover is eliminated. Free choline has 
been reported to exchange with preformed phosphatidylcholine in vitro by a phospholipase $\mathrm{D}$ catalysed reaction which bypasses phosphocholine and CDP-choline (Dils \& Hubscher, 1961). However, embryo phosphatidylcholine is as stable in choline-containing as in normal media (Table 3), suggesting that, in common with many other tissues (Nagley \& Hallinan, 1968; Pasternak \& Friedrichs, 1970), this pathway does not operate in vivo in mouse embryos and hence does not contribute to choline incorporation into phospholipid. Comparisons of the stability of phospholipid at different embryonic stages were made by pre-labelling embryos and monitoring the loss of lipid into (non-radioactive) normal or choline-containing media (Table 3). Embryos prelabelled with $\left[\right.$ methyl ${ }^{3} \mathrm{H}$ ]choline before the pre-compacted 8-cell, fully compacted morula or blastocyst stages lost $10-40 \%$ of the labelled lipid during $24 \mathrm{~h}$ of their subsequent development (Table 3). Since choline-dependent exchange does not occur (Table 3), the loss of phospholipid label is probably due to phospholipid turnover (Pasternak \& Bergeron, 1970). This is not unexpected since turnover of membrane phospholipid is considered to be a normal and growth-regulated characteristic of viable cells (Pasternak \& Friedrichs, 1970; Dawson, 1973) and has previously been demonstrated to occur during the later stages of cleavage in the sea urchin embryo (Pasternak, 1973). The stability of embryonic choline-containing phospholipid is comparable to that of phosphatidylcholine in other mammalian cells in which half-lives of 24-36 h have been recorded (Pasternak \& Friedrichs, 1970; Pasternak \& Bergeron, 1970).

Since choline base exchange and phospholipid turnover account for little if any of the [methyl- ${ }^{3} \mathrm{H}$ ]choline incorporation observed, then this incorporation must represent de-novo synthesis of phospholipid and its accumulation by the mouse embryo. An increase in phospholipid synthesis per embryo was observed during the development of the 2-cell embryo to the morula stage under experimental conditions which minimize variations in the intracellular specific activity of the precursor (Text-fig. 2; Table 1) and hence permit comparisons of relative synthetic rates. The low level of phospholipid synthesis measured at the 2-cell stage $(0.026 \mathrm{pmol}$ [methyl- ${ }^{3} \mathrm{H}$ ]choline/embryo/4 h) (Table 1) is not unexpected since the first cleavage division involves little change in surface area (Izquierdo, 1977) or content of intracellular organelles (Calarco \& Brown, 1969). The two cleavage divisions from the 2-cell to the 8-cell stage and the subsequent compaction of the morula (approx. 12 cells) are associated with a doubling of the plasma membrane surface area (Izquierdo, 1977) as well as substantial proliferation of intracellular membrane-bound organelles. These demands for additional membrane assembly correlate with a 9-13-fold increase in phospholipid synthesis $\left(0.24\right.$ pmol [methyl- ${ }^{3} \mathrm{H}$ ]choline/pre-compaction embryo $/ 4 \mathrm{~h}$ and $0.35 \mathrm{pmol}$ [methyl- ${ }^{3} \mathrm{H}$ ]choline/post-compaction embryo/4 h) (Table 1). When calculated on a per cell basis these results demonstrate that the rate of phospholipid synthesis doubles from the 2-cell to the 8-cell stage and then remains relatively constant during compaction. Choline incorporation is also elevated in the blastocyst $\left(0.26 \mathrm{pmol}\right.$ [methyl ${ }^{3} \mathrm{H}$ ]choline/blastocyst $\left./ 4 \mathrm{~h}\right)($ Table 1$)$, although the relative rate of phospholipid synthesis cannot be estimated due to limitations in choline transport at this stage (Text-fig. 2).

The lipid composition (principally that of phospholipid and cholesterol) is now known to have a profound influence on the fluidity of the lipid bilayer (Lee, 1975), and lateral mobility and biological properties of its component proteins (Lee, 1975; Kimelberg, 1977), as well as the ability of the cell to respond to external stimuli and undergo mitosis (Horwitz et al., 1974). The work reported here highlights features of embryo membrane phospholipids. Firstly, the absence of detectable sphingomyelin synthesis within a $4 \mathrm{~h}$ labelling period could be due to the slower rate of turnover of this lipid (Pasternak \& Friedrichs, 1970) in comparison with phosphatidylcholine. However, prolonged labelling $(>24 \mathrm{~h})$ with [methyl ${ }^{3} \mathrm{H}$ ]choline also failed to label the sphingomyelin fraction, implying that there is minimal, if any, synthesis of this lipid during morula and blastocyst formation. Other studies have shown that undifferentiated cells, including those of the early embryo, are deficient in sphingomyelin: e.g. sea urchin eggs and embryos (Kozhina, Terekhova \& Svetashez, 1978), plasma membranes of immature and 
leukaemic lymphocytes (Gottfried, 1967) and immature liver cells (Eberspacher, Organisciak \& Massaro, 1977). Possible implications of this deficiency have been discussed (Pratt, 1978).

Secondly, the extent of lysolecithin formation in TCA extracts and deacylation of exogenous phospholipid by embryo extracts (H. P. M. Pratt, unpublished observations) suggest that phospholipase A-type activity is present in mouse embryos before implantation as well as in spermatozoa (Conway \& Metz, 1976) and post-implantation embryos (East, Chepenik \& Waite, 1975). In other systems modifications of the fatty acyl composition of membrane phospholipids have been shown to promote cell adhesion and membrane destabilization facilitating cell fusion (discussed by Pratt, 1978).

The results presented in this paper demonstrate that the preimplantation mouse embryo is capable of synthesizing phospholipid de novo and hence is equipped to assemble new cellular membranes. Membrane lipids should prove to be useful marker molecules for studying the synthesis and assembly of embryonic cell membranes and for providing information on the molecular basis of changes in membrane properties which influence cellular responses to differentiative stimuli during early mammalian embryogenesis.

I thank Dr M. H. Johnson, Dr P. R. Braude and Dr D. Bowyer for helpful discussions and Ms Gin Flach for excellent technical assistance. The work was supported by grants from the Ford Foundation to Professor C. R. Austin, and the Medical Research Council.

\section{References}

Bergeron, J.J.M., Warmsley, A.M.H. \& Pasternak, C.A. (1970) Phospholipid synthesis and degradation during the life-cycle of P815Y mast cells synchronised with excess of thymidine. Biochem. J. 119, 489-492.

Biggers, J.D. \& Borland, R.M. (1976) Physiological aspects of growth and differentiation of the preimplantation mammalian embryo. Ann. Rev. Physiol. 38, 95-119.

Biggers, J.D., Whitten, W.K. \& Whittingham, D.G. (1971) The culture of mouse embryos in vitro. In Methods in Mammalian Embryology, pp. 86-116. Ed. J. C. Daniel, Jr. W. H. Freeman, San Francisco.

Biggers, J.D., Borland, R.M. \& Powers, R.D. (1977) Transport mechanisms in the preimplantation mammalian embryo. In The Freezing of Mammalian Embryos (Ciba Fdn Symp. No. 52 (New Series)), pp. 129-146. Elsevier/North-Holland, Amsterdam.

Borland, R.M. \& Tasca, R.J. (1974) Activation of a $\mathrm{Na}^{+}$-dependent amino acid transport system in preimplantation mouse embryos. Devl Biol. 36, 169183.

Brinster, R.L., Wiebold, J.L. \& Brunner, S. (1976) Protein metabolism in preimplantation mouse ova. Devl Biol. 51, 215-224.

Calarco, P.G. \& Brown, E.A. (1969) An ultrastructural and cytological study of preimplantation development of the mouse. J. exp. Zool. 171, 253-284.

Chepenik, K.P., Borst, D.E. \& Waite, B.M. (1977) Cholinephosphotransferase activities in early rat embryos and their associated placentas. Devl Biol. 60, 463-472.

Conway, A.F. \& Metz, C.B. (1976) Phospholipase activity of sea urchin sperm: its possible involvement in membrane fusion. J. exp. Zool. 198, 39-48.

Cooper, R.A. (1977) Abnormalities of cell membrane fluidity in the pathogenesis of disease. New Engl. J. Med. 297, 371-376.

Dawson, R.M.C. (1960) A hydrolytic procedure for the identification and estimation of individual phospholipids in biological samples. Biochem. J. 75, 45-53.

Dawson, R.M.C. (1973) The exchange of phospholipids between cell membranes. Subcellular Biochem. 2, 69-89.

Dils, R.R. \& Hubscher, G. (1961) Metabolism of phospholipids. III. The effect of calcium ions on the incorporation of labelled choline into rat liver microsomes. Biochim. Biophys. Acta 46, 505-513.

Ducibella, T., Albertini, D.F., Anderson, E. \& Biggers, J.D. (1975) The preimplantation mammalian embryo: Characterisation of intercellular junctions and their appearance during development. Devl Biol. 45, 231-250.

Ducibella, T., Ukena, T., Karnovsky, M.\& Anderson, E. (1977) Changes in cell shape and cortical cytoplasmic organisation during embryogenesis of the preimplantation mouse embryo. J. Cell Biol. 74, $153-167$.

East, J.M., Chepenik, K.P. \& Waite, B.M. (1975) Phospholipase(s) A activities in rat placentas of 14 days' gestation. Biochim. Biophys. Acta 388, 106-112.

Eberspacher, B.E. Organisciak, D.T. \& Massaro, E.J. (1977) Alterations in lipid composition of liver cell plasma membranes during development. J. exp. Zool. 199, 289-296.

Edidin, M. (1976) The appearance of cell-surface antigens in the development of the mouse embryo: a study of cell surface differentiation. In Embryogenesis in Mammals (CIBA Fdn Symp. No. 40 (new Series)), pp. 177-194. Elsevier, Amsterdam.

Folch, J., Lees, M. \& Sloane-Stanley, G.H. (1957) A 
simple method for the isolation and purification of total lipids from animal tissues. J. biol. Chem. 226, 497-509.

Gottfried, E.L. (1967) Lipids of human leukocytes: relation to cell type. J. Lipid Res. 8, 321-327.

Granholm, N.H. \& Brenner, G.M. (1976) Effects of Cytochalasin B (CB) on morula to blastocyst transformation and trophoblast outgrowth in the early mouse embryo. Expl Cell Res. 101, 143-153.

Horwitz, A.F., Hatten, M.E. \& Burger, M.M. (1974) Membrane fatty acid replacement and their effect on growth and lectin-induced agglutinability. Proc. natn. Acad. Sci. U.S.A. 71, 3115-3119.

Izquierdo, L. (1977) Cleavage and differentiation. In Development in Mammals, Vol. 2, pp. 99-118. Ed. M. H. Johnson. North-Holland, Amsterdam.

Johnson, M.H. (1979) Instrinsic and extrinsic factors in preimplantation development. J. Reprod. Fert. 55, 255-265.

Johnson, M.H., Handyside, A.H. \& Braude, P.R. (1977) Control mechanisms in early mammalian development. In Development in Mammals, Vol. 2, pp. 6797. Ed. M. H. Johnson. North-Holland, Amsterdam.

Kennedy, E.P. (1957) Metabolism of lipids. Ann. Rev. Biochem. 26, 119-148.

Kimelberg, H.K. (1977) The influence of membrane fluidity on the activity of membrane-bound enzymes. In Dynamic Aspects of Cell Surface Organisation, Vol. 3, pp. 205-279. Eds G. Poste \& G. L. Nicolson. Elsevier/North-Holland/Biomedical Press, Amsterdam.

Kozhina, V.P., Terekhova, T.A. \& Svetashez, V.l. (1978) Lipid composition of gametes and embryos of the sea urchin Strongylocentrotus intermedius at early stages of development. Devl Biol. 62, 512-517.

Kuff, E.L., Hymer, W.C., Shelton, E. \& Roberts, N.E. (1966) The in vivo protein synthesis activities of free versus membrane-bound ribonucleoproteins in a plasma cell tumour of the mouse. J. Cell Biol. 29, 63-75.

Lee, A.G. (1975) Functional properties of biological membranes: a physical chemical approach. Progr. Biophys. molec. Biol. 29, 3-56.

Nagley, P. \& Hallinan, T. (1968) The use of radioactive choline as a specific label for microsomal membranes. 1. Selectivity of label for endoplasmic reticulum and specificity for lecithin. Biochim. Biophys. Acta 163, 218-225.
Pasternak, C.A. (1973) Phospholipid synthesis in cleaving sea urchin eggs: model for specific membrane assembly. Devl Biol. 30, 403-410.

Pasternak, C.A. \& Bergeron, J.J.M. (1970) Turnover of mammalian phospholipids. Stable and unstable components in neoplastic mast cells. Biochem. J. 119, $473-480$.

Pasternak, C.A. \& Friedrichs, B. (1970) Turnover of mammalian phospholipids. Rates of turnover and metabolic heterogeneity in cultured human lymphocytes and in tissues of healthy, starved and Vitamin A deficient rats. Biochem. J. 119, 481-488.

Plagemann, P.G.W. (1968) Choline metabolism and membrane formation in rat hepatoma cells grown in suspension culture. Archiv. Biochem. Biophys. 128, $70-87$.

Plagemann, P.G.W. (1971) Choline metabolism and membrane formation in rat hepatoma cells grown in suspension culture. III. Choline transport and uptake by simple diffusion and lack of direct exchange with phosphatidylcholine. J. Lipid Res. 12, 715-724.

Pratt, H.P.M. (1977) Uterine proteins and the activation of embryos from mice during delayed implantation. J. Reprod. Fert. 50, 1-8.

Pratt, H.P.M. (1978) Lipids and transitions in embryos. In Development in Mammals, Vol. 3, pp. 83-129. Ed. M. H. Johnson. North-Holland, Amsterdam.

Pratt, H.P.M., Fitzgerald, P.A. \& Saxon, A. (1977) Synthesis of sterol and phospholipid induced by the interaction of phytohemagglutinin and other mitogens with human lymphocytes and their relation to blastogenesis and DNA synthesis. Cell Immunol. 32, 160170.

Rothman, J. \& Lenard, J. (1977) Membrane asymmetry. Science, N.Y. 195, 754-753.

Schneider, W.C. (1969) Enzymatic preparation of labelled phosphorylcholine, phosphorylethanolamine, cytidine diphosphate choline, deoxycytidine diphosphate, cytidine diphosphate ethanolamine and deoxycytidine diphosphate ethanolamine. Methods Enzymol. 14, 684-690.

Simpson, R.W. \& Hauser, R.E. (1966) Infiuence of lipids on the viral phenotype. Virology 30, 684-697.

Yorio, T. \& Bentley, P.J. (1976) Stimulation of active Na transport by phospholipase C. Nature, Lond. 261, $722-723$.

Whittingham, D.G. \& Wales, R.G. (1969) Storage of 2cell mouse embryos in vitro. Austr. J. biol. Sci. 22, 1065-1066.

Received 17 May 1979 